\title{
UDC 629.45.027.3
}

\author{
O. H. REIDEMEISTER ${ }^{1 *}$, A. V. LAGUZA ${ }^{2 *}$ \\ 1*Dep. «Car and Car Facilities», Dnipropetrovsk National University of Railway Transport named after Academician \\ V. Lazaryan, Lazaryan St., 2, Dnipro, Ukraine, 49010, tel. +38 (056) 37315 04, e-mail reidemeister@mail.ru, \\ ORCID 0000-0001-7490-7180 \\ ${ }^{2 *}$ Dep. «Car and Car Facilities», Dnipropetrovsk National University of Railway Transport named after Academician \\ V. Lazaryan, Lazaryan St., 2, Dnipro, Ukraine, 49010, tel. +38 (056) 37315 04, e-mail nastaci@ yahoo.com, \\ ORCID 0000-0001-8811-7243
}

\section{DETERMINATION OF CHARACTERISTICS OF THROTTLING DEVICE FOR PNEUMATIC SPRING}

Purpose. This paper focuses on determination of the dependence of the working medium flow on the capacity of the throttling device, its geometric features and the pressure difference in the pneumatic spring cylinder and in the auxiliary reservoir. Methodology. Calculation of the dependence of the working medium and pressure drop is performed in two ways: 1) by numerical simulation of a stationary gas flow through a throttling element; 2) its analytical calculation expression using empirical relationships (control calculation to evaluate the reliability of numerical simulation results). For the calculation, three models of throttling devices were chosen. Dependence of the flow rate of the working medium on the capacity of the throttling device and its geometric features was determined based on the approximation of the dependency graphs of the pressure drop against the mass flow rate of the working medium. Findings. We obtained graphical dependencies between the pressure drop and the mass flow rate of the working medium from the two calculation options. Based on the results of calculations performed with the help of a software package with visualization of the results, we calculated a proportionality coefficient that describes the dependence of the working medium flow on the throttling device capacity and its geometric features for each of the throttling elements considered, with three degrees of closure. The air flow values, obtained by numerical simulation, are greater than the flow rates obtained from semi-empirical formulas. At the same time, they are in good qualitative agreement, and the quantitative difference averages $25 \%$, which can be regarded as confirmation of the reliability of the numerical model. Based on the calculation results, we plotted the proportionality coefficient graphs against the degree of closure of the throttling device. Originality. The work allows determining the degree of influence of the frictional component on the variation of the pressure difference in the pneumatic cylinder and the auxiliary reservoir of the pneumatic suspension system. Also, the work proposes a method to determine the dependence of the working medium on the capacity of the throttling device and its geometric features. Practical value. The ability to predict the operating parameters of the pneumatic system depending on the pneumatic resistance of the throttling device will improve the car running characteristics, increase the comfort of passenger transport, and also reduce the wear of the rolling stock and track gauge due to vehicle-track interaction.

Keywords: spring suspension; pneumatic spring; pressure drop

\section{Introduction}

Recently, pneumatic springs have become very widely used on trans-regional trains, high-speed trains $[3,16]$. The advantage of pneumatic spring as an element of spring suspension is that it can be used to realize large static deflections in the secondary spring suspension (up to $300 \mathrm{~mm}$ ) and to obtain a noise reduction in the passenger compartments. In addition, for lines with raised platforms it is necessary to maintain a constant floor height of the car regardless of the number of passengers in the car. This is provided by the operation of a le- velling valve and pneumatic springs [16]. It is necessary to consider the generalized structure of an equivalent mechanical model, adopted on the basis of pneumatic spring tests (Fig. 1) [3].

The ability to perceive high horizontal and diagonal movements, as well as torsional resistance, makes pneumatic suspension systems an attractive solution for all types of bogies [3, 16].

In general, the pneumatic suspension system (Fig. 2) on the car has the form of the pneumatic cylinder 1 and the auxiliary reservoir 4 connected to each other $[17,19,22]$. To regulate the dissipative and elastic properties of the pneumatic suspen- 
sion system, the throttling element 2 is located in the connection fitting 3 .

To calculate the properties of the pneumatic system shown in Figure 1, there is a significant number of mechanical models.

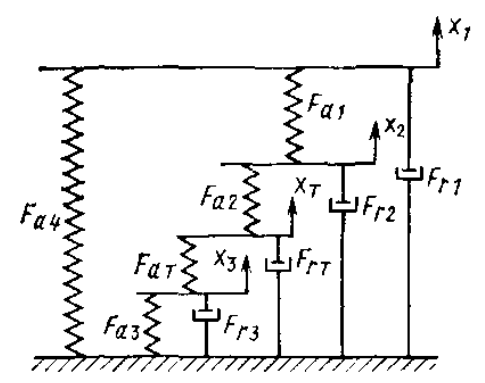

Fig. 1. Generalized structure of equivalent mechanical system

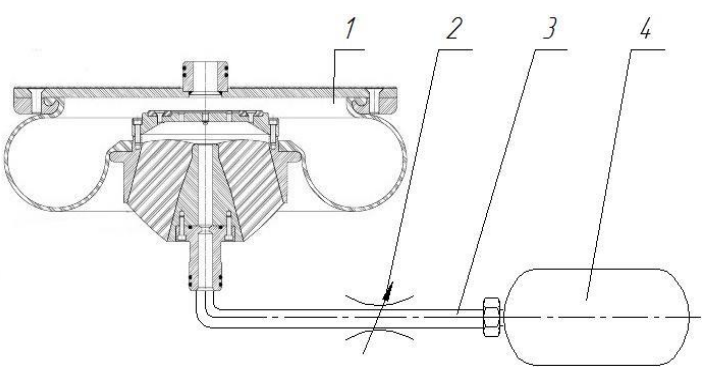

Fig. 2. Diagram of pneumatic spring with reservoir

This model is based on the analysis of the graphs obtained during the pneumatic spring tests. The model consists of elements with instantaneous contacts, represented in the same way as in the first model, in the form of a connection between elastic and dissipative elements. Herewith, in the model, each of the elastic elements with a force $F_{a}$ and dissipative ones with a force $F_{r}$ enables a physical interpretation, which allows us to propose a corresponding approximating expression for it. In particular, the elements with forces $F_{a 1}, F_{a 2}, F_{a 3}$ model the elastic properties of the main and additional capacity of air suspension. The elastic element with a force $F_{a 1}$ simulates the change in the effective area of the pneumatic cylinder when it deforms and the elasticity of the rubber-cord shell. The law of change is determined by the results of a static calibration of the pneumatic springs and approximated by a piecewise-linear relationship.

The elements $F_{r 1}$ and $F_{r 2}$ simulate losses due to air throttling. At the same time, the element $F_{r 3}$ works mainly at low velocities of deformation of the pneumatic cylinder (subcritical mode of air flow through the throttle opening); the element $F_{r 2}$ is switched on at the deformation rate of the pneumatic spring when the supercritical mode of air flow through the throttle occurs.

However, the awkwardness of the model and a significant number of parameters limit its wide application in theoretical calculations.

Another structural scheme for the calculation of pneumatic spring is presented in [6] (Fig. 3).

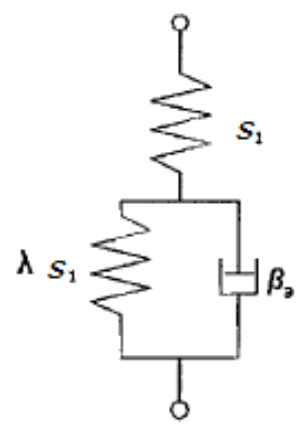

Fig. 3. Mechanical model of pneumatic spring

The presented model of the pneumatic spring takes into account the static stiffness of the pneumatic cylinder $S_{1}$, the effect of changing the ratio of air volumes in the pneumatic cylinder and the auxiliary reservoir to the stiffness of the pneumatic spring $\lambda S_{1}$ and the damping coefficient of the equivalent viscous friction of the pneumatic spring $\beta_{e}$.

The defining parameters of this pneumatic spring scheme are: the load-bearing capacity of the spring, the parameters of the throttling device and air.

This model gives fairly accurate results in the case of small oscillations.

The more complex and frequently used model is the Nishimura pneumatic spring model (Fig. 4). The Nishimura pneumatic spring model was developed more than 40 years ago $[9,10,15,18]$. The model takes into account the changes in the stiffness of the pneumatic cylinder $K_{1}$ and the reservoir $K_{2}$, depending on the change in air volumes in them, $K_{3}$ is a change in the level of stiffness of the pneumatic cylinder. The model can take into account both linear and quadratic changes in 
the viscosity index $C$. That allows using it both for modelling the stiffness of a pneumatic balloon and for determining the resistance to air flow through a connecting armature.

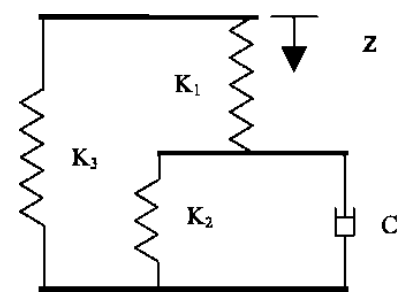

Fig. 4. Model of Nishimura pneumatic spring

VAMPIRE model is an extension of the Nishimura model $[9,18,19]$ with quadratic attenuation. In addition, inertial effect $M$ and auxiliary stiffness $k$ are introduced (Fig. 5).

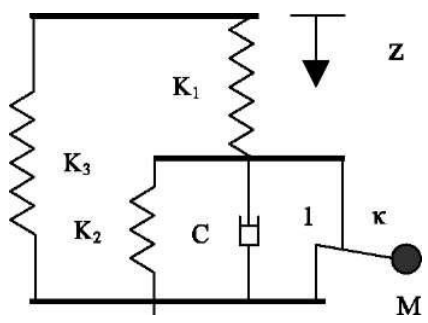

Fig. 5 Model of VAMPIRE pneumatic spring

Berg pneumatic springs model, often found in the literature under the name GENSYS, is threedimensional and can describe transverse, longitudinal and vertical oscillations $[9,11,14,18,20$, 24]. It is worth mentioning that the model describes several parameters of the spring: elasticity, friction and viscosity. The vertical model has a nonlinear attenuation, which depends on the rate of change in pressure in the pneumatic cylinder.

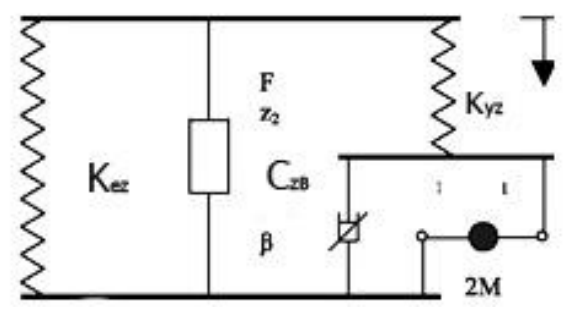

Fig. 6. Model of GENSYS (Berg) pneumatic spring

There is another model of pneumatic springs Bouc-Wen [12, 13, 18, 21], which includes not only elastic and dissipative elements describing the state of gas in the system, but also a block that simulates changes in the condition of the rubbercord shell of a pneumatic cylinder.

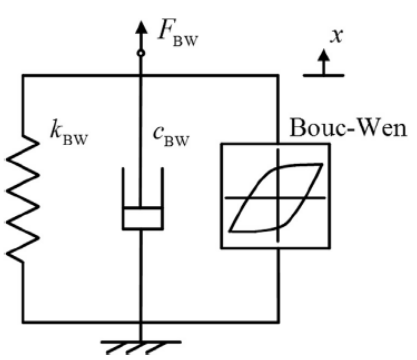

Fig. 7. Model of Bouc-Wen pneumatic spring:

$F_{B W}$ - vertical force from the body, $k_{B W}$ - non-linear elastic stiffness, $c_{B W}$-damping component

To describe the behavior of pneumatic springs, the mechanical model includes three parallel branches: non-linear elastic stiffness $k_{B W}$; damping component $c_{B W}$; block, which determines the parameters of the pneumatic cylinder operation depending on the behavior of the rubber-cord shell Bouc-Wen.

The branch with nonlinearly elastic stiffness is used to simulate the work of air within the pneumatic spring and to describe its geometric parameters, as well as the thermodynamic processes that take place within the pneumatic spring, which can be derived in accordance with the thermodynamic equation.

The branch with a damping component is used to simulate the resistance of the air flow in the pipe of the system «pneumatic cylinder - connecting fittings - auxiliary reservoir».

The friction branch is a block simulating a hysteresis loop and amplitude dependences.

The widespread model is considered to be that $[1,17]$ describing the pneumatic spring as a connection between the parallel installed elastic element with stiffness $C$ and viscous friction element with viscosity $\beta$ (Fig. 8).

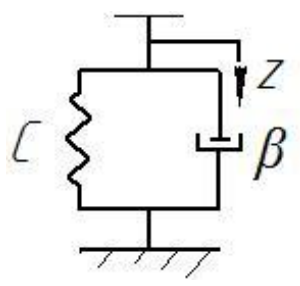

Fig. 8. Equivalent mechanical system

In the previously mentioned schemes, the role of the throttling device was performed by additionally introduced viscosity parameters. 
Throttle is local adjustable or non-adjustable resistance, set in the way of the working fluid flow [1].

The main throttle characteristics are the metering and tuning characteristics. The metering characteristic is the relationship between air flow through the throttle and the ratio of pressures before and after the throttle. The metering characteristic largely depends on the regime of laminar or turbulent flow. The flow regime is determined from the Reynolds number. When $R_{e}<R_{c r}$ the flow is considered laminar, when $R_{e}>R_{c r}$-turbulent.

According to functional purposes, the throttles are classified into constant and variable ones. According to the principle of operation, there are linear and quadratic throttles.

Constant throttles are generally an orifice in the plate. They are conventionally divided into throttling plugs and bushings.

The wide class of adjustable throttles include: cylindrical, conical needle, threaded, throttles such as «rotary valve», flapper-nozzle and spool-type throttling valves, as well as the role of a throttle can be performed by throttling valves.

\section{Purpose}

The purpose of this work is to determine the dependence of the working medium flow on the capacity of the throttling device, its geometric features and the pressure difference in the pneumatic spring cylinder and in the auxiliary reservoir.

An important task in the course of the work will be to determine the pressure difference when the working medium passes through the throttling element. The necessary part of the work is also to determine the reliability of the results obtained when determining the pressure difference in the throttling device.

\section{Methodology}

Calculation of the dependence of the working medium and pressure drop is performed in two ways:

- By numerical simulation of a stationary gas flow through a throttling element;

- Its analytical calculation expression using empirical relationships (control calculation to evaluate the reliability of numerical simulation results).
We selected several different types of throttling devices [4, 5], namely: corrosion-proof throttle valve Aisi 304 (L)/316 (L) DN 40 (Fig. 9); San Marino valves for air, gases and liquids normally open of type «T» (Figure 10) and type «Y» (Figure 11) with G11/4» connecting thread.

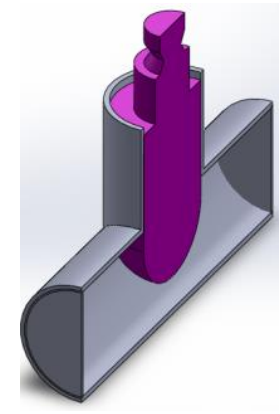

Fig. 9. Corrosion-proof throttle valve Aisi 304 (L)/316 (L) DN 40

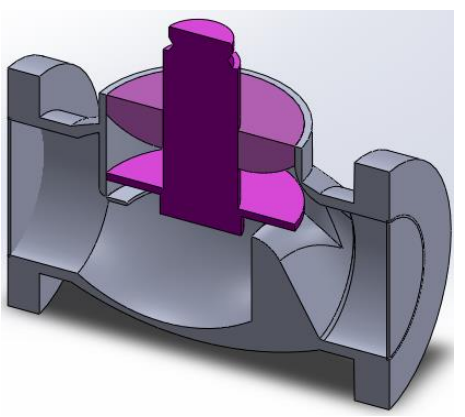

Fig. 10. San Marino valve for air, gases and liquids normally open of type «T»

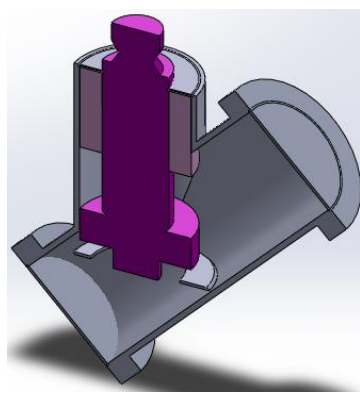

Fig. 11. San Marino valve for air, gases and liquids normally open of type «Y»

The diameters of the inlet and outlet openings are $40 \mathrm{~mm}$. The length of the Aisi throttle valve body is $160 \mathrm{~mm}$, San Marino valves for air, gases and liquids normally open of type $\langle\mathrm{T} »-120 \mathrm{~mm}$ and type «Y» $-113 \mathrm{~mm}$.

For analysis, we selected three stem positions: open $-\ll 0 »$, closed by $50 \%-\langle 1 / 2 »$, closed by $75 \%-\ll 3 / 4 »$. 
In numerical simulation, we consider the motion of the working medium (air) in the cavity of the throttling element represented by the 3D model. The flow is stationary turbulent. The boundary conditions are given as follows (Figure 12). The surface that bounds the cavity is divided into three areas:

- inlet opening - the pressure is determined;

- outlet opening - the mass air flow is determined;

- walls - all motion speed components are zero.

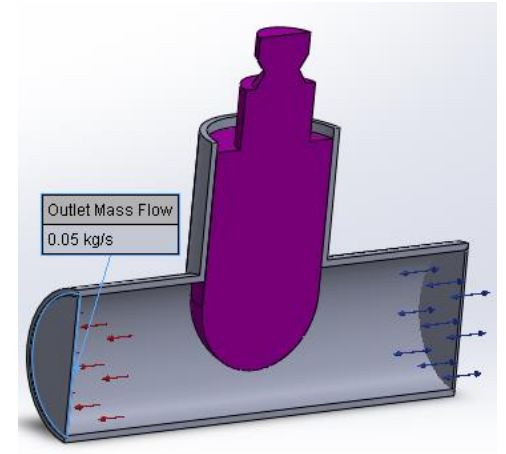

Fig. 12. Boundary conditions

The air movements describe the averaged Navier-Stokes equations with two additional equations of the k- $\varepsilon$ model of turbulent flow [25].

As the input data, we set the pressure of the working medium obtained in calculations of the generalized pneumatic spring model in the Matlab Simulink software package [23]. The change in the flow rate of the working medium at the outlet from the throttling device is set in the range from 0.001 $\mathrm{kg} / \mathrm{s}$ to $0.26 \mathrm{~kg} / \mathrm{s}$, also according to the previously obtained data.

The calculation is carried out at the environmental temperature equal to $20^{\circ} \mathrm{C}$. The software package allows taking into account the properties of various materials used in the design of throttling devices, such as a bronze body, a brass plate, a steel stem. Therefore, in order to take into account the different degrees of resistance when the working medium rubs against the surface, one of the input parameters indicates the type of material.

During the calculation it is possible to see not only the final result, as a diagram with pressure values, but also to trace the nature of the working medium flow at any point of the throttling device (Fig. 13).

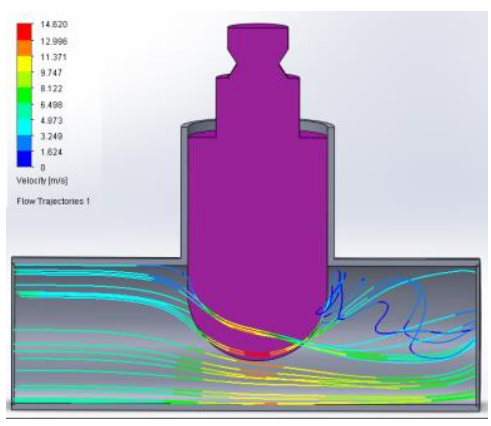

Fig. 13. Distribution of velocities of the working medium in the throttling device

Based on the results of calculations, graphs of the dependence of the pressure drop on the flow rate of the working medium are plotted.

To evaluate the reliability of the results obtained, we perform calculations using the formulas given in $[1,2,8]$.

$$
R_{e}=\frac{4 \cdot r_{h} \cdot \omega \cdot \rho}{\eta_{d}},
$$

where $r_{h}$-hydraulic radius of the channel section, $\mathrm{m} ; \omega$ - average velocity of compressed gas flow along the channel section, $\mathrm{m} / \mathrm{s} ; \rho-$ gas density, $\mathrm{kg} / \mathrm{m}^{3} ; \quad \eta_{d}-$ coefficient of dynamic viscosity, determined from the diagrams [7], Pa s.

$$
\omega=\frac{G}{\rho \cdot F},
$$

where $G$ - mass flow rate of gas, $\mathrm{kg} / \mathrm{s} ; F$ - crosssectional area of the channel, $\mathrm{m}^{2}$.

The density of compressed gas for working pressure is calculated by the formula:

$$
\rho=\frac{\left(P_{a}+P_{o v}\right) \cdot \mu}{R \cdot T},
$$

where $P_{a}-$ atmospheric pressure, $\mathrm{kPa}$; $P_{o v}$ - overpressure in the system of pneumatic springs, $\mathrm{kPa} ; R$ - universal gas constant, $\mathrm{J} /(\mathrm{mol}$ $\mathrm{K}) ; T$ - temperature, $\mathrm{K} ; \mu$ - molar mass of gas, mol.

The pressure loss depends on two coefficients of resistance: the coefficient of resistance $\varsigma_{f r}$ characterizing the frictional losses during the movement of the working fluid and the local loss factor at the input $\varsigma_{\text {in }}$. 
The coefficient of resistance, characterizing the friction loss, is determined by the formula:

- at the gas motion, when $R_{c r}<R_{e}<10^{5}$, we use the Blasius formula:

$$
\varsigma_{f r}=0.314 \cdot R_{e}^{-0.25},
$$

- at the gas motion, when $10^{5}<R_{e}<10^{8}$, we use the formula Nikuradze:

$$
\varsigma_{f r}=0.00332+0.221 \cdot R_{e}^{-0.237},
$$

The coefficient of local losses at the input $\zeta_{i n}$ is determined depending on the shape and geometric dimensions of the inlet opening [2].

The coefficients of local losses in many cases are determined from tables and graphs obtained experimentally. So the local loss coefficients for the presented throttling elements are selected from the reference tables $[2,8]$.

The loss of pressure is determined by the formula $[2,8]$ :

$$
\Delta P=\varsigma \cdot \frac{\omega^{2} \cdot \rho}{2},
$$

According to the obtained data, graphs of dependence of pressure drop on mass flow were also constructed for further comparison with the calculation in the shown complex with the visualization of calculations.

The dependence of the flow rate of the working medium on the type of throttling device will be determined based on the approximation of the graphs of the dependence of the pressure drop on the mass flow:

$$
G=\alpha \cdot \sqrt{\Delta P},
$$

where $\alpha$-proportionality coefficient.

\section{Findings}

The graphical dependences of the mass flow rate of the working medium $G$ on the pressure difference $\Delta P$ are shown in Fig. 14-16 (based on the results of numerical simulation) and in Fig. 17-19 (based on calculations using empirical dependencies). The degree of closure of the throttling device is denoted by $\varphi$.

The value of the air flow, obtained by numerical simulation, is greater than the flow rates ob- tained from semi-empirical formulas. At the same time, they are in good qualitative agreement, and the quantitative difference averages $25 \%$, which can be regarded as confirmation of the reliability of the numerical model.

As can be seen from the Figures 14-16, the graphs are well approximated by the function $G=\alpha \cdot \sqrt{\Delta P}$, which allows us to show the dependence of the working medium flow rate on the type of throttling device. Calculation using a software package with visualization of the results gives more accurate data and visually realizes the process occurring in the throttling device than the calculation using approximate formulas.

Based on the results of calculations performed with the help of a software package with visualization of the results, we calculated a proportionality coefficient that describes the dependence of the working medium flow on the throttling device capacity and its geometric features for each of the throttling elements considered, with three degrees of closure.

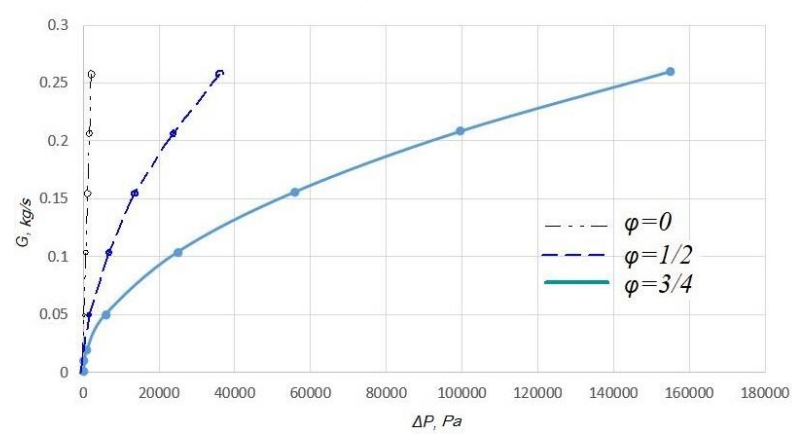

Fig. 14. Graph of the mass flow rate versus the pressure difference of Aisi throttle valve based on the mathema-tical modelling results

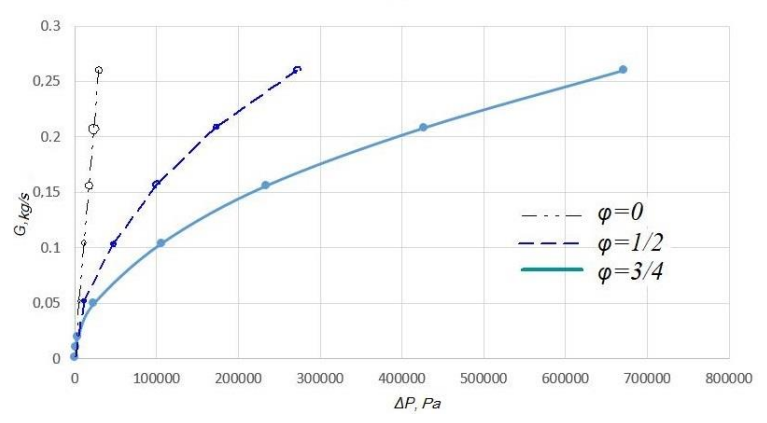

Fig. 15. Graph of the mass flow rate versus the pressure difference for San Marino valve type «T» based on the mathematical modelling results 


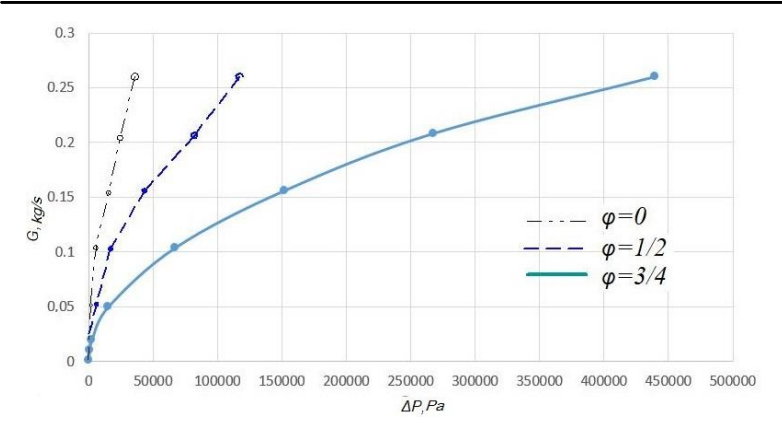

Fig. 16. Graph of the mass flow rate versus the pressure difference for San Marino valve type «Y» based on the mathematical modelling results

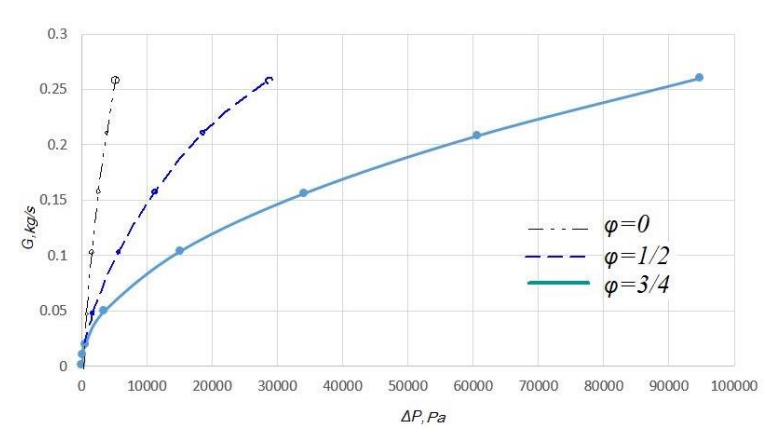

Fig. 17. Graph of the mass flow rate versus the pressure difference for Aisi throttle valve based on the calculation results using empirical dependencies

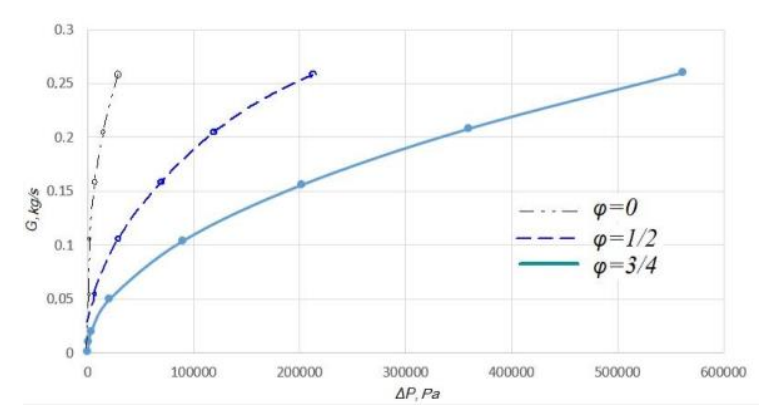

Fig. 18. Graph of the mass flow rate versus the pressure difference for San Marino valve type «T» based on the calculation results using empirical dependencies

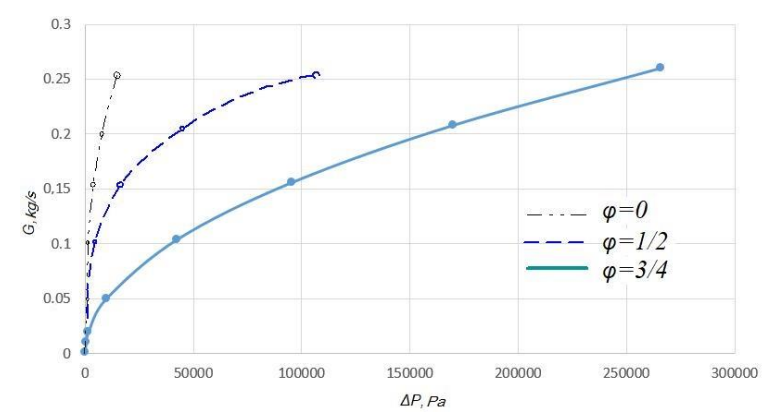

Fig. 19. Graph of the mass flow rate versus the pressure difference for San Marino valve type «Y» based on the calculation results using empirical dependencies

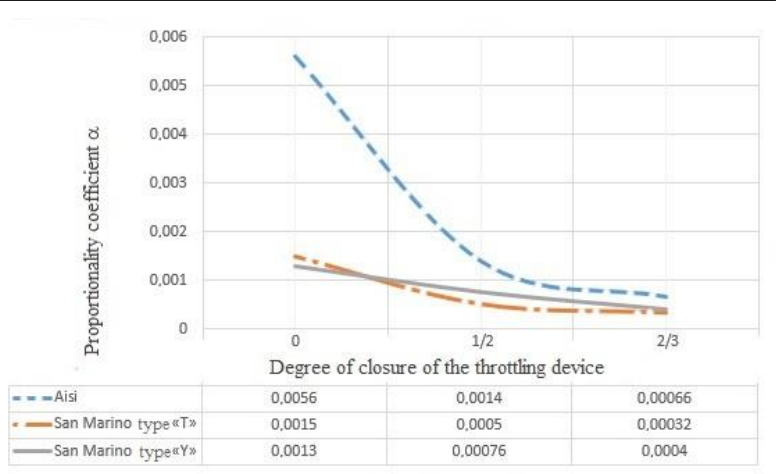

Fig. 20. Graph of the mass flow rate versus the type of throttling device

\section{Originality and practical value}

The work allows determining the degree of influence of the frictional component on the variation of the pressure difference in the pneumatic cylinder and the auxiliary reservoir of the pneumatic suspension system. Also, the work proposes a method to determine the dependence of the working environment on the capacity of the throttling device and its geometric features.

The practical value lies in the possibility to predict the operating parameters of the pneumatic system depending on the pneumatic resistance of the throttling device will improve the car running characteristics, increase the comfort of passenger transport, and also reduce the wear of the rolling stock and track gauge due to vehicle-track interaction.

\section{Conclusions}

Analyzing the above graphs, we can conclude that the use of modern computational complexes with visualization of the results greatly increases the accuracy of calculation and allows analyzing the operation of the system and the state of the working medium in it not only by the final results in digital form, but also observing them directly at the time of flow process.

The obtained data of the pressure drop dependence on the working medium mass flow allowed determining the law that describes the process flowing in the throttling devices. The dependence of the flow rate of the working medium on the capacity of the throttling device and the geometric capabilities of its design is determined. 


\section{LIST OF REFERENCE LINKS}

1. Гидропневмоавтоматика и гидропривод мобильных машин. Средства гидропневмоавтоматики : учеб. пособие / А. Ф. Андреев, П. П. Артемьев, П. Р. Бартош [и др.]. - Минск : ВУЗ-ЮНИТИ БГПА-ИСН, 1998. - $224 \mathrm{c}$.

2. Идельчик, И. Е. Справочник по гидравлическим сопротивлениям / И. Е. Идельчик. - Москва : Машиностроение, 2011. $-672 \mathrm{c}$.

3. Камаев, В. А. Оптимизация параметров ходовых частей железнодорожного подвижного состава / В. А. Камаев. - Москва : Машиностроение, 1980. - 215 с.

4. Клапан дроссельный нержавеющий AISI 304(L)/316(L) [Electronic resource]. - Available at: http://www.progressteel.com.ua/armatura/drosselnyjj-klapan/. - Title from the screen. - Accessed : 09.01.2018.

5. Клапаны для воздуха, газа и жидкостей с пневмоуправлением (San Marino) [Electronic resource]. - Available at: http://docplayer.ru/39907306-Klapany-dlya-vozduha-gazov-i-zhidkostey-s-pnevmoupravleniem-sanmarino.html. - Title from the screen. - Accessed : 09.01.2018.

6. Механическая часть тягового подвижного состава : учеб. для вузов ж.-д. трансп. / И. Б. Бирюков, А. Н. Савоськин [и др.]. - Москва : Транспорт, 1992. - 440 с.

7. Справочник машиностроителя : в 6 т. / под ред. проф. Ачеркана Н. С. - Москва : Гос. науч.-тех. изд-во машиностр. лит-ры, 1956. - Т. 2. -574 с.

8. Чугаев, Р. Р. Гидравлика (Техническая механика жидкости) : учеб. для вузов / Р. Р. Чугаев. - 4-е изд., доп. и перераб. - Ленинград : Энергоиздат, Ленингр. отд-ние, 1982. - 672 с.

9. Abid, H. J. Equivalent Air Spring Suspension Model for Quarter-Passive Model of Passenger Vehicles / H. J. Abid, J. Chen, A. A. Nassar // International Scholarly Research Notices. - 2015. - Vol. 2015. - P. 1-6. doi: 10.1155/2015/974020.

10. Ahmed, M. I. Mathematical Modeling and Control of Active Suspension System for a Quarter Car Railway Vehicle [Electronic resource] / M. I. Ahmed, M. Y. Hazlina, M. M. Rashid // Malaysian J. of Mathematical Sciences. - 2016. - Vol. 10 (S). - P. 227-241. Available at: http://einspem.upm.edu.my/ journal/fullpaper/vol10sfeb2/No20.pdf. - Title from the screen. - Accessed : 09.01.2018.

11. Aizpun, M. Using the stationary tests of the acceptance process of a rail vehicle to identify the vehicle model parameters / M. Aizpun, J. Vinolas, A. Alonso // Proc. of the Institution of Mechanical Engineers. Part F: J. of Rail and Rapid Transit. - 2014. - Vol. 228. - Iss. 4. - P. 1-14. doi: $10.1177 / 0954409713478592$.

12. A novel air spring dynamic model with pneumatic thermodynamics, effective friction and viscoelastic damping / Hengjia Zhu, James Yang, Yunqing Zhang, Xingxing Feng // Journal of Soundand Vibration. - 2017. Vol. 408. - P. 87-104. doi: 10.1016/j.jsv.2017.07.015.

13. A novel MR device with variable stiffness and damping capability / Shiyu Zhao, Huaxia Deng, Jin Zhang, Liandong Yu, Shuaishuai Sun, Weihua Li, Laijun Zhou // Intern. Journal of Aerospace and Lightweight Structures. - 2013. - Vol. 3. - Iss. 3. - P. 325-335. doi: 10.3850/S2010428613000032.

14. Docquier, N. Model-based evaluation of railway pneumatic suspensions / N. Docquier, P. Fisette, H. Jeanmart // Vehicle System Dynamics: Intern. J. of Vehicle Mechanics and Mobility. - 2008. - Vol. 46. - P. 481-493. doi: $10.1080 / 00423110801993110$.

15. Gialleonardo, E. D. The influence of track modelling options on the simulation of rail vehicle dynamics / Egidio Di Gialleonardo, Francesco Braghin, Stefano Bruni // Journal of Sound and Vibration. - 2012. Vol. 331. - P. 4246-4258. doi: 10.1016/j.jsv.2012.04.024.

16. Iwnicki, S. Handbook of Railway Vehicle Dynamics / S. Iwnicki. - Boca Raton : CRC Press, 2006. - 552 p. doi: $10.1201 / 9781420004892$.

17. Mathematical modelling of the secondary airspring suspension in railway vehicles and its effect on safety and ride comfort / A. Facchinetti, L. Mazzola, S. Alfi, S. Bruni // Vehicle System Dynamics: International Journal of Vehicle Mechanics and Mobility. - 2010. - Vol. 48. - Iss. S 1. - P. 429-449. doi: 10.1080/00423114.2010.486036.

18. Mazzola, L. Secondary suspension of railway vehicles - air spring modelling: Performance and critical issues / L. Mazzola, M. Berg // Journal of Rail and Rapid Transit. - 2014. - Vol. 228. - Iss. 3. - P. 225-241. doi: $10.1177 / 0954409712470641$.

19. Multiphysics modelling of multibody systems: application to car semi-active suspensions / N. Docquier, A. Poncelet, M. Delannoy, P. Fisette // Vehicle System Dynamics: International Journal of Vehicle Mechanics and Mobility. - 2010. - Vol. 48, No. 12. - P. 1439-1460. doi: 10.1080/00423110903509335. 
20. Multiphysic modelling of railway vehicles equipped with pneumatic suspensions / N. Docquier, A. Poncelet, M. Delannoy, P. Fisette // Vehicle System Dynamics: International Journal of Vehicle Mechanics and Mobility. - 2007. - Vol. 46, No. 6. - P. 505-524. doi: 10.1080/00423110601050848.

21. Nonlinear dynamic model of air spring with a damper for vehicle ride comfort / H. Zhu, J. Yang, Y. Zhang, X. Feng, Z. Ma // Nonlinear dynamic. - 2017. - Vol. 89. - Iss. 2. - P. 1545-1568. doi: 10.1007/s11071-017-3535-9.

22. Raju, K. R. Vineeth Developments in vibration control of structures and structural components with magnetorheological fluids / K. R. Raju, D. V. Varma // Current Science. - 2017. - Vol. 112. - Iss. 3. - P. $499-508$. doi: $10.18520 / \mathrm{cs} / \mathrm{v} 112 / \mathrm{i} 03 / 499-508$.

23. Reidemeister, O. H. Dependence of air spring parameters on throttle resistance / O. H. Reidemeister, A. V. Kivisheva // Наука та прогрес транспорту. - 2016. - № 2 (62). - P. 157-164. doi: $10.15802 /$ stp2016/67339.

24. Sayyaadi, H. A New model in rail vehicles dynamics considering nonlinear suspension components behavior / H. Sayyaadi, N. Shokouhi // International Journal of Mechanical Sciences. - 2009. - Vol. 55. - P. $222-232$. doi: 10.1016/j.ijmecsci.2009.01.003.

25. Wilcox, D. C. Turbulence modeling for CFD / D. C. Wilcox. - La Cañada Flintridge, California : DCW Industries, Inc. La Canada, 1994. - 460 p.

\section{О. Г. РЕЙДЕМЕЙСТЕР ${ }^{1 *}$, А. В. ЛАГУЗА ${ }^{2 *}$}

\section{${ }^{1 *}$ Каф. «Вагони та вагонне господарство» Дніпропетровський національний університет залізничного транспорту імен академіка В. Лазаряна, вул. Лазаряна, 2, Дніпро, Україна, 49010, тел. +38 (056) 37315 19, ел. пошта reidemeister@mail.ru, ORCID 0000-0001-7490-7180 \\ ${ }^{2 *}$ Каф. «Вагони та вагонне господарство» Дніпропетровський національний університет залізничного транспорту імені академіка В. Лазаряна, вул. Лазаряна, 2, Дніпро, Україна, 49010, тел. +38 (056) 37315 19, ел. пошта nastaci@yahoo.com, ORCID 0000-0001-8811-7243 \\ ВИЗНАЧЕННЯ ХАРАКТЕРИСТИК ДРОСЕЛЮЮЧОГО ПРИСТРОЮ ДЛЯ ПНЕВМАТИЧНОЇ РЕСОРИ}

Мета. У науковій роботі необхідно розглянути визначення залежності витрати робочого середовища від пропускної здатності дроселюючого пристрою, його геометричних особливостей, різниці тисків у балоні пневматичної ресори та в додатковому резервуарі. Методика. Розрахунок залежності кількості робочого тіла та перепаду тиску виконаний двома способами: 1) чисельним моделюванням стаціонарного потоку газу через дроселюючий пристрій; 2) аналітичним розрахунковим виразом із використанням емпіричних залежностей (контрольний розрахунок для оцінки достовірності результатів чисельного моделювання). Для розрахунку було обрано три моделі дроселюючих пристроїв. Залежність витрат робочого середовища від пропускної здатності дроселюючого пристрою була визначена, виходячи 3 апроксимації графіків залежності перепадів тисків від масових витрат робочого середовища. Результати. Отримано графічні залежності між перепадом тисків і масовими витратами робочого середовища за двома варіантами розрахунку. Із розрахунків, проведених за допомогою програмного комплексу з візуалізацією результатів, обчислений коефіцієнт пропорційності. Він описує залежність витрат робочого середовища від пропускної здатності дроселюючого пристрою з урахуванням геометричних особливостей для кожного з розглянутих елементів при трьох ступенях їх закриття. Значення витрат повітря, отримані шляхом чисельного моделювання, більше ніж значення, знайдені за напівемпіричними формулами. У той же час, вони знаходяться в хорошій якісній відповідності, а кількісна різниця становить у середньому 25 \%, що можна розглядати як підтвердження достовірності чисельної моделі. За результатами розрахунків побудовані графіки залежності коефіцієнта пропорційності від ступеня закриття дроселюючого пристрою. Наукова новизна. Робота дозволяє виявити ступінь впливу складової сили тертя на зміну різниці тисків у пневмобалоні та додатковому резервуарі системи пневматичного підвішування. Також у роботі пропонується спосіб виявлення залежності витрат робочого середовища від пропускної здатності дроселюючого пристрою. Практична значимість. Можливість прогнозування параметрів пневматичної системи залежно від пневматичного опору дроселюючого пристрою дозволить поліпшити ходові характеристики вагонів, підвищити комфортабельність перевезення пасажирів, а також знизити знос рухомого складу та рейкової колії внаслідок взаємодії «екіпаж-шлях».

Ключові слова: ресорне підвішування; пневматична ресора; втрати тиску 


\begin{abstract}
А. Г. РЕЙДЕМЕЙСТЕР ${ }^{1 *}$, А. В. ЛАГУЗА ${ }^{2 *}$
1*Каф. «Вагоны и вагонное хозяйство», Днепропетровский национальный университет железнодорожного транспорта имени академика В. Лазаряна, ул. Лазаряна, 2, Днипро, Украина, 49010, тел. +38 (056) 37315 19,

эл. почта reidemeister@mail.ru, ORCID 0000-0001-7490-7180

${ }^{2 *}$ Каф. «Вагоны и вагонное хозяйство», Днепропетровский национальный университет железнодорожного транспорта имени академика В. Лазаряна, ул. Лазаряна, 2, Днипро, Украина, 49010, тел. +38 (056) 3731519 , эл. почта nastaci@yahoo.com, ORCID 0000-0001-8811-7243
\end{abstract}

\title{
ОПРЕДЕЛЕНИЕ ХАРАКТЕРИСТИК ДРОССЕЛИРУЮЩЕГО УСТРОЙСТВА ДЛЯ ПНЕВМАТИЧЕСКОЙ РЕССОРЫ
}

Цель. В научной работе необходимо рассмотреть определение зависимости расхода рабочей среды от пропускной способности дросселирующего устройства, его геометрических особенностей, разности давления в баллоне пневматической рессоры и в дополнительном резервуаре. Методика. Расчет зависимости рабочей среды и перепада давления выполнен двумя способами: 1) численным моделированием стационарного потока газа через дросселирующее устройство; 2) аналитическим расчетным выражением с использованием эмпирических зависимостей (контрольный расчет для оценки достоверности результатов численного моделирования). Для расчета было выбрано три модели дросселирующих устройств. Зависимость расхода рабочей среды от пропускной способности дросселирующего устройства и его геометрических особенностей была определена, исходя из аппроксимации графиков зависимости перепада давления от массового расхода рабочей среды. Результаты. Получены графические зависимости между перепадом давлений и массовым расходом рабочей среды по двум вариантам расчета. Из расчетов, проведенных с помощью программного комплекса с визуализацией результатов, вычислен коэффициент пропорциональности. Он описывает зависимости расхода рабочей среды от пропускной способности дросселирующего устройства с учетом его геометрических особенностей для каждого из рассмотренных элементов при трех степенях закрытия. Значения расхода воздуха, полученные путем численного моделирования, больше значений расхода, найденных по полуэмпирическим формулам. В то же время, они находятся в хорошем качественном соответствии, а количественная разница составляет в среднем 25 \%, что можно рассматривать как подтверждение достоверности численной модели. По результатам расчетов построены графики зависимости коэффициента пропорциональности от степени закрытия дросселирующего устройства. Научная новизна. Работа позволяет выявить степень влияния составляющей силы трения на изменение разности давлений в пневмобаллоне и дополнительном резервуаре системы пневматического подвешивания. Также в работе предлагается способ выявления зависимости затрат рабочей среды от пропускной способности дросселирующего устройства и его геометрических особенностей. Практическая значимость. Возможность прогнозирования рабочих параметров пневматической системы в зависимости от пневматического сопротивления дросселирующего устройства позволит улучшить ходовые характеристики вагонов, повысить комфортабельность перевозки пассажиров, а также снизить износ подвижного состава и рельсовой колеи вследствие взаимодействия «экипаж-путь».

Ключевые слова: рессорное подвешивание; пневматическая рессора; потери давления

\section{REFERENCES}

1. Andreev, A. F., Artemev, P. P., Bartosh, P. R., Bartashevich, L. V., Bogdan, N. V., Korolkevich, A. V. \& Metlyuk, N. F. (1998). Gidropnevmoavtomatika $i$ gidroprivod mobilnykh mashin. Sredstva gidropnevmoavtomatiki: Uchebnoe posobie. Minsk: VUZ-YuNITI BGPA-ISN. (in Russian)

2. Idelchik, I. Y. (1992). Spravochnik po gidravlicheskim soprotivleniyam. Moscow: Mashinostroenie. (in Russian)

3. Kamaev, V. A. (1980). Optimizatsiya parametrov khodovykh chastey zheleznodorozhnogo podvizhnogo sostava. Moscow: Mashinostroenie. (in Russian)

4. Klapan drosselnyy nerzhaveyushchiy AISI 304(L)/316(L). Retrived from http://www.progressteel.com.ua/ armatura/drosselnyjj-klapan/. (in Russian)

5. Klapany dlya vozdukha, gaza i zhidkostey s pnevmoupravleniem (San Marino). Retrived from http://docplayer.ru/ 39907306-Klapany-dlya-vozduha-gazov-i-zhidkostey-s-pnevmoupravleniem-san-marino.html. (in Russian)

6. Biryukov, I. B., Savoskin, A. N., \& Burchak G. P. et al. (1992). Mekhanicheskaya chast tyagovogo podvizhnogo sostava: Uchebnik dlya vuzov zheleznodorozhnogo transporta. Moscow: Transport. (in Russian) 
7. Acherkan, N. S. (Ed). (1956). Spravochnik mashinostroitelya. (Vol. 1-6). Moscow: Gosudarstvennoe nauchnotekhnicheskoe izdatelstvo mashinostroitelnoy literatury. (in Russian)

8. Chugaev, R. R. (1982). Gidravlika (Tekhnicheskaya mekhanika zhidkosti): Uchebnik dlya vuzov. Leningrad: Energoizdat, Leningradskoe otdelenie. (in Russian)

9. Abid, H. J., Chen, J., \& Nassar, A. A. (2015). Equivalent Air Spring Suspension Model for Quarter-Passive Model of Passenger Vehicles. International Scholarly Research Notices, 2015, 1-6. doi: 10.1155/2015/974020. (in English)

10. Ahmed, M. I., Hazlina, M. Y., \& Rashid, M. M. (2016). Mathematical Modeling and Control of Active Suspension System for a Quarter Car Railway Vehicle. Malaysian J. of Mathematical Sciences, 10(S), $227-241$. Retrived from http://einspem.upm.edu.my/journal/fullpaper/vol10sfeb2/No20.pdf. (in English)

11. Aizpun, M., Vinolas, J., \& Alonso, A. (2014). Using the stationary tests of the acceptance process of a rail vehicle to identify the vehicle model parameters. Proc. of the Institution of Mechanical Engineers. Part F: J. of Rail and Rapid Transit, 228(4), 1-14. doi: 10.1177/0954409713478592. (in English)

12. Hengjia Zhu, James Yang, Yunqing Zhang, \& Xingxing Feng (2017). A novel air spring dynamic model with pneumatic thermodynamics, effective friction and viscoelastic damping. Journal of Soundand Vibration, 408, 87-104. doi: 10.1016/j.jsv.2017.07.015. (in English)

13. Shiyu Zhao, Huaxia Deng, Jin Zhang, Liandong Yu, Shuaishuai Sun, Weihua Li, \& Laijun Zhou (2013). A novel MR device with variable stiffness and damping capability. Intern. Journal of Aerospace and Lightweight Structures, 3(3), 325-335. doi: 10.3850/S2010428613000032. (in English)

14. Docquier, N., Fisette, P., \& Jeanmart, H. (2008). Model-based evaluation of railway pneumatic suspensions. Vehicle System Dynamics: International Journal of Vehicle Mechanics and Mobility, 46, 481-493. doi: 10.1080/00423110801993110. (in English)

15. Gialleonardo, E. D., Braghin, F., \& Bruni, S. (2012). The influence of track modelling options on the simulation of rail vehicle dynamics. Journal of Sound and Vibration, 331, 4246-4258. doi: 10.1016/j.jsv.2012.04.024. (in English)

16. Iwnicki, S. (2006). Handbook of Railway Vehicle Dynamics. Boca Raton: CRC Press. doi: 10.1201/9781420004892. (in English)

17. Facchinetti, A., Mazzola, L., Alfi, S., \& Bruni, S. (2010). Mathematical modelling of the secondary airspring suspension in railway vehicles and its effect on safety and ride comfort. Vehicle System Dynamics: International Journal of Vehicle Mechanics and Mobility, 48(1), 429-449. doi: 10.1080/00423114.2010.486036. (in English)

18. Mazzola, L., \& Berg, M. (2014). Secondary suspension of railway vehicles - air spring modelling: Performance and critical issues. Journal of Rail and Rapid Transit, 228(3), $225-241$. doi: 10.1177/0954409712470641. (in English)

19. Docquier, N., Poncelet, A., Delannoy, M., \& Fisette, P. (2007). Multiphysic modelling of railway vehicles equipped with pneumatic suspensions. Vehicle System Dynamics: International Journal of Vehicle Mechanics and Mobility, 46(6), 505-524. doi: 10.1080/00423110601050848. (in English)

20. Docquier, N., Poncelet, A., Delannoy, M., \& Fisette, P. (2010). Multiphysics modelling of multibody systems: application to car semi-active suspensions. Vehicle System Dynamics: International Journal of Vehicle Mechanics and Mobility, 48(12), 1439-1460. doi: 10.1080/00423110903509335. (in English)

21. Zhu, H., Yang, J., Zhang, Y., Feng, X., \& Ma, Z. (2017). Nonlinear dynamic model of air spring with a damper for vehicle ride comfort. Nonlinear dynamic, 89(2), 1545-1568. doi: 10.1007/s11071-017-3535-9. (in English)

22. Raju, K. R., \& Varma, D. V. (2017). Vineeth Developments in vibration control of structures and structural components with magnetorheological fluids. Current Science, 112(3), 499-508. doi: 10.18520/cs/v112/i03/499-508. (in English)

23. Reidemeister, O. H., \& Kivisheva, A. V. (2016). Dependence of air spring parameters on throttle resistance. Science and Transport Progress, 2(62), 157-164. doi: 10.15802/stp2016/67339. (in English)

24. Sayyaadi, H., \& Shokouhi, N. (2009). A New model in rail vehicles dynamics considering nonlinear suspension components behavior. International Journal of Mechanical Sciences, 55, 222-232. doi: 10.1016/j.ijmecsci.2009.01.003. (in English)

25. Wilcox, D. C. (1994). Turbulence modeling for CFD. La Cañada Flintridge, California: DCW Industries, Inc. La Canada. (in English)

Prof. S. V. Myamlin, D. Sc. (Tech.), (Ukrain) recommended this article to be published

Received: Sept. 22, 2017

Accessed: Jan. 10, 2018 